Прегледни чланак

doi:10.5937/zrpfns46-2412

Réka Pusztahelyi, Assistant

Faculty of Law Miskolc

\title{
THE TIME LIMITS FOR ENFORCING CLAIMS AND EXERCISING RIGHTS: PRECLUSIVE TERMS AND PERIODS OF LIMITATION IN THE LIGHT OF THE PROPOSAL OF THE NEW HUNGARIAN CIVIL CODE
}

\begin{abstract}
The New Proposal of the Hungarian Civil Code was submitted to the Parliament by the Government on 11 July, 2012. Reviewing the provisions on prescription and terms of preclusion, it attempts to harmonize the current judicial practice, the international background and the legal tradition of the Hungarian civil law with the effective legal regulation. The present paper reviews the changes in the provisions related to prescription and preclusive terms, and investigates whether the internal coherence of the provisions has been achieved. The paper surveys provisions on prescription of the Draft Common Frame of Reference and the Convention on the Limitation Period in the International Sale of Goods.
\end{abstract}

Key words: prescription, period of limitation, preclusive term

\section{Introduction}

The Proposal of the Committee for Codification on a new Civil Code was published on the Government's websites on 15 February, 2012. In July the Government submitted the Proposal to the Parliament. ${ }^{1}$ This Proposal (hereinafter referred to as Proposal) - follows the path of the earlier drafts $^{2}$, but diverges

1 This text (Bill No. T/7971. on the Civil Code) is available at: http://www.parlament.hu/internet/plsql/ogy_irom.irom_adat?p_ckl=39\&p_izon=7971

${ }^{2}$ This study takes no notice of the overview of the process and achievements of the codification in the field of prescription had been begun for more than ten years. For entire review of this 
from the rules of the effective Civil Code. The review of the present provisions was based upon the achievements of the judicature, which are incorporated in the new text.

Along the codification of new provisions related to the time limits for enforcing claims and exercising rights, the Legislature intended to make clear what the differences between them are and which claims fall under the statute of limitation and which do not. The review of the time limits and claims brought new solutions and the present study draws attention to the future changes and points out the provisions which can be criticized.

\section{Drawing a distinction between prescription and preclusive term}

\subsection{Theoretical background}

The problems relating to the period of limitation and preclusive term arouse conflicting opinions in the old Hungarian civil law. Gáspár Menyhárt analysing the current Hungarian and German doctrine - stated that the passing of time, in itself does not result in the lapsing or extinction of rights (claims).

"Even the appearance shall be avoided, that time has certain legal consequences. Nevertheless, the non-using of a right is the fact which causes the extinction of right." 3

The claims flowing from the rights that have been violated can be enforced depending on the creditor's intention, thus, the law sets time-bars against enforcing the claim in favour of the debtor and for the reason of legal-political purposes. On the basis of all these facts, the prescription is nothing but: „, the omission of enforcing a claim for a time set" 4

Albert Kiss wrote in his 1902 study $^{5}$ that the period of prescription and the time limit (preclusive term) can be either handled rigorously, as different legal institutions or, they can be placed on the same scale as different results of the same legal event (the un-use of right for a given period time).

Moreover, Loránt Rudolf also pointed out the great variety of issues in the analysis of the legal phenomena similar to prescription. It comes into sight that neither the cases of prescription, nor the cases of the preclusive terms can be looked at in a uniform manner. ${ }^{6}$

\footnotetext{
progression see: Professor György BíRÓ: The institution of prescription. „Az elévülés intézménye" (In: Sectio Juridica et Politico, Miskolc, Tomus XXVI/2. (2008), 541-557. pp.)

${ }^{3}$ MENYHÁRT, Gáspár: Prescription and preclusive term. Elévülés és záros határidő (Ajtai Nyomda, Kolozsvár, 1917.) 20. p.

${ }^{4}$ op. cit.. 22.p.

${ }^{5}$ KISS, Albert: The prescription in the Hungarian civil law of today. Az elévülés a mai magyar magánjogban. (Budapest, Grill K. 1902. ) 128.p.

${ }^{6}$ RudOLF, Loránt: The prescription. Az elévülés. (KJK Budapest 1961.) 48-50. pp.
} 
Theoretically, it is worth drawing a distinction between the periods on the basis of the following attributes:

As stated above, the Legislature generally sets the preclusive terms expressed in provisions, while the rest are manifested in periods of limitation. When the period of limitation lapses, the opportunity for enforcing a claim in court action ceases but the mere right remains, so the voluntary performance of the claim cannot be reclaimed by the debtor (as unjustified enrichment), and collateral claims are enforceable (nowadays so the lien in moveable things as pledge). When the preclusive term is passed, the substantial right ceases, and the performance lacks its legal base (title). The court acting in the legal proceeding has to notice the cessation of right ex officio, without the need for an exception of the debtor. The passing of the period of limitation (prescription) has a legal effect only if the debtor files an exception of prescription. Otherwise the court must decide on the action of creditor (plaintiff). Time-barred claims are not enforceable in court action. Generally, preclusive term is not subject to suspension or interruption. In the case of preclusive term, no event has effect on the computation of time. If the creditor has already brought an action within the period, the court may not stay the proceedings which have already begun to run. The period of limitation can be tolled, i.e. suspended or interrupted. Every legal system sets the events which are able to toll the period in the manner described.

\subsection{The ,vanishing right”}

In the view of the facts stated above, we could ask whether there are only period of limitation and preclusive terms.

The old legal literature of civil law acknowledged the possibility to vanish a right without reference to the above mentioned terms. If the creditor did not exercise his right without any reason for a long time, and his behaviour (the non-using) shows that he intends to waive the right, this waiver resulted in the vanishing of right. There are judicial decisions interpreting in this manner the provisions concerning the following rights: the right for reclaiming the gift (under the provisions concerning donation contract) ${ }^{7}$ and the right for judicial statement that the contract violating right of pre-emption has no legal force ${ }^{8}$, may cease if the creditor waives his right by implied conduct within the period of limitation or preclusive term.

The Proposal sets time (three years) for enforcing claims arising from an ineffective contract, violating the right of pre-emption ${ }^{9}$, thus it narrows the cases of the ,right-vanishing”. It must be noted here that the Proposal does not

\footnotetext{
${ }^{7}$ Standpoint No. 76. adopted by Civil Law Chamber of Supreme Court (Curia)

${ }^{8}$ Decision on principle No. 1408. of 2006.

${ }^{9}$ Proposal Art. 6:224. para. (2)
} 
set time for reclaiming the gift, but states that ${ }^{10}$ it is to be regarded as a waiver, if the creditor does not reclaim the gift for a long time without any adequate reason.

In his proposal István Kemenes has raised ${ }^{11}$ the issue, how to relate the claims arising from a legal relationship (regulated by provisions of the Book of Obligation in the New Civil Code) to the provisions on prescription. He sketched three answers:

,-- The preclusive or limiting nature of periods are generally common feature of the civil substantial law periods, thus any (all) period can be ranked into either preclusive or limiting category; or

- the preclusive or limiting nature of a period emerges in the narrower sense, only in those cases, when the civil law orders terms for enforcing any substantive right, claim; or

- the preclusive or limiting nature of a period is applicable only for the claims from obligations"

Though the approach of the use of rights, the enforcing claims (which concentrates only on the period of time), is not so fortunate, it reveals that the point of view which was taken into consideration during the codification of the new civil code was that preclusive or limiting periods are the only existing time form for exercising rights and enforcing claims.

\section{On the limiting nature of certain periods of time}

\subsection{Term for avoidance}

According to the provisions of Hungarian civil law, the invalidity of a contract can mean nullity (absolute form of invalidity) or voidability (relative form of invalidity which depends on the contestation; i.e. on the written notification by the aggrieved party). Pursuant to the effective Hungarian Civil Code, the other party shall be given written notification of a contestation within one year, and if the notification is not successful, the contestation shall be immediately enforced in court. ${ }^{12}$ This time limit commences upon recognition of the mistake or fraud; (in the case of unlawful menace), upon the cessation of coercion; or on the performance (in the case of conspicuous discrepancy). ${ }^{13}$ Under the effective regulation, the provision of prescription, suspension and interruption are ade-

\footnotetext{
${ }^{10}$ Proposal Art 6:238. para. (4)

11 KEMENES, István: Issues relating to the effect of the time running . Az idömúlás joghatásával összefüggő egyes kérdések. http://www.szitb.hu/doc/polgari/idomulas.pdf; downloaded: 7th of May 2012.

${ }^{12}$ CC Art. 236. para. (1)

${ }^{13}$ CC Art 236. para. (3)
} 
quately applicable for this period of time. ${ }^{14}$ Contrarily, the Proposal ceases the events, from which the period commences. At first sight this could mean that this period becomes a preclusive term, because the legal provision does not state whether it is a prescription period or preclusive term. The Proposal remains silent about the application of the provisions of the suspension or interruption.

However, a recently published Commentary of Proposal of Committee reveals the real reason of the modification. According to the opinion of the Committee for Codification, the time for contestation is a period of limitation. Thus all events upon which the period for contestation can commence under the effective provision also suspend the period of limitation (the creditor is unable to enforce a claim for an excusable reason, because of a hindrance). But it must be considered here that the Commentary may be mis-formulated: ,[Thus] ... in the case of the cessation of hindrance (which lasts in case of mistake until the recognition in case of mistake, in case of unlawful menace it lasts till the cessation of situation of menace) the period of limitation begins to run from the cessation of the excusable reason." "15

According to the effective rule on suspension which is reserved by the Proposal, the excusable reason suspends the running of the period only if the period of limitation has already lapsed or there is less than one year or less than three months, remaining therein, when the creditor can enforce his claim again. If we regard the time limit for contestation as period of prescription, and therefore the application of the provisions on the suspension of period is necessary, the provision is logically incorrect. According to that the creditor can enforce his claim in court action within a period of one year reckoned from the conclusion of contract, in case of the debtor had been given a written notification for a contestation and the contestation was unsuccessful. In my opinion the period of prescription can be suspended during negotiation, and this hindrance can lengthen the period for enforcing the claim over the original one year period of prescription.

\subsection{Impeachment of a will}

In the effective Hungarian Civil Code, under section $\S$ 653: "Beneficiaries shall be entitled to enforce their claims to have a will declared invalid or inoperative at any time." Thus the operative provision on invalidity (or ineffective will) does not set any time limit for enforcing a claim arising from the invalid (ineffective) will. The Commentary on the original text of the Civil Code de-

14 The Justification of the original text of CC regards this time limit for contestation as a preclusive term. Act No. 4 of year 1959. and the Annotation for Hungarian Civil Code [published by Ministry of Justice, KJK, Budapest, 1959.] .375. p.

${ }^{15}$ op. cit. 380. p. 
clares that to inheritance claims the provisions on ownership claims (to which no statute of limitations applies) and the provisions on contract law (which are subject to limitation/prescription) are applicable. So, considering this duality, the effective Civil Code does not set time limit for the enforcing a claim arising from invalid (ineffective) will. On the ground of these facts, the judicial practice of the operative Civil Code acknowledged the imperishableness of an allegation of a will being invalid or inoperative, as it regarded the inheritance claim as ownership claim. ${ }^{16}$

Contrarily, the Proposal sets time limit to the claim against invalid will, the general five year period of prescription is to be applied. ${ }^{17}$ The Commentary of Proposal declares that „the claim (of an heir) for contestation against an invalid (ineffective) will is not an ownership claim, but an obligational one, which is enforceable within a period of prescription."

\subsection{Time limits for the enforcing claims arising from deficient performance}

The Proposal basically changes the consequence of the deficient performance. Apart from these significant changes it is important to take into consideration that the Proposal ceases the preclusive time limit for the enforcing of warranty claim. It also comes from the above that the reason was the numerous legal problems arising from the simultaneous time limits, which could not be resolved by judicial practice.

Considering the changes of the provision on time limits for enforcing warranty claim in the Civil Code, it has been found that the issue has not come to a rest since the publication of the Code Civil of year 1959. The Act No. 4/1959 i.e. the operative Civil Code originally set only preclusive time limit for the warranty claim enforcing:

"The warranty claim will be enforced in court action within a 6 months period unless the parties had not set guarantee for a longer period. The lack of claim enforcing within the legal period results in cessation of the right. ${ }^{18}$

Thus the liability of the debtor ends with the expiration of the preclusive period. The judicial practice lightened the strictness of the preclusive period so far as that the summer break of jurisdiction has not been considered in the viewpoint of the passing of the period. More problems arose from that the par-

${ }^{16}$ See: Gellért, György (ed.): Commentary of the Civil Code. A Polgári Törvénykönyv Magyarázata (7th edition, Complex Kiadó, Budapest, 2007.) 2443.p. But the claim for compulsory share of inheritance is subject to prescription.

17 "The right for litigation of a will is under statute of limitation, within 5 year of the day on which the succession opened." Proposal, Art. 7:37. para. (4)

${ }^{18}$ CC (from 1st May 1960 to 1st Mars 1978) Art. 306. para. (3)-(4). 
ticular provisions on the warranty claims (i.e. supply contracts, agricultural product sales contracts) prescribed not only different periods, but also periods of prescription. The Justification of Ministry of Justice added to the significant amendment of the Civil Code in year of 1977 pointed out that the particular provisions concerning contracts between economic organizations - on the base of the authorization under the Paragraph (3) / Art 405 of Civil Code - regulated differently the enforcing of warranty claims.

The above mentioned significant amendment of the Civil Code in 1977 touched upon the periods for enforcing the warranty claims. The double periods of time, prescription and preclusive period were born. The next amendment lengthened the period of prescription to 2 years and the preclusive term to 3 years in consumer contracts.

The Supreme Court of Hungary published a decision on principles regulating and interpreting the relation between the period of prescription and the preclusive term. ${ }^{19}$ The decision expounds that the general provisions on prescription are to apply to the period of limitation for enforcing warranty claims. If the creditor cannot enforce his claim for an excusable reason, the warranty claim shall remain enforceable within 3 months form the cessation of the hindrance, even if the period of limitation has already lapsed or there is less than three months remaining therein. Thus this decision stated that the warranty claim could be enforceable even if the preclusive period has already lapsed.

In the No 1/2004 Opinion of Civil Law Chamber (mentioned above already) the Supreme Court pointed out that in case of suspension of the period of limitation, the creditor can enforce his warranty claim within this new period of one year or 3 months, but within the preclusive period. The new judicial interpretation of these provisions can be read from this opinion even if the opinion does not declare that it swerves from the earlier practice of jurisdiction.

Back to the new Civil Code and its Commentary, the argument that the reason for ceasing the preclusive period was that the judicial practice was not able to solve the problem rising from the collision between the preclusive term and the period of limitation is not acceptable. If the preclusive term lapsed, it ceased the both the right and the enforceable claim included, thus the right cannot be enforceable in court action soon after, even if the creditor could prove an excusable reason which suspended the passing of the period.

That argument sounds better that it is unworthy setting preclusive term and period of limitation too, for the claim enforcing, as the period of limitation is sufficient to temporally restrain the objective responsibility of the debtor. The

${ }^{19}$ PED-GED No. I. Decision on principle published the Economy and Civil Law Chamber of Supreme Court (on the time limits related to enforcing claims rising up from the indeficient performance.) 
significant lengthening of the period of limitation shall prevent the interrupting events with restricting (or strictly interpreting them), particularly if we take into consideration that the Proposal intends to cease the written notice for performance as an interrupting event.

\section{The provisions concerning prescription ${ }^{20}$ in the new Civil Code}

\subsection{The emplacement of prescription in the new Proposal}

The Proposal placed the provisions on prescription among the general rules of obligations in the First Part of the Book of Obligation. This shows that rights (claims) subjected to prescription can arise not only from contractual relations, but from any obligation. The title of the chapter was changed to „Prescription" from ,Prescription and preclusive term”, which title was given in the new Civil Code (Act No. CXX/2009) that never came into force (furthermore referred to as new Civil Code). Thus the question arises what is the correlation between the prescription and the preclusive term. In relation to this, it is worth noticing that after the turn of the century the opinions in the literature discussed with regard to the Drafts of civil code (1900-1928) or without reference to them are not uniform considering the relation between prescription and preclusive term. In accordance with the wording of the Proposal:

„, The expiry of a period of time ordered by legal provision for exercising a right or enforcing a claim may extinct the right, if so expressly prescribed by law. If the period of time is not preclusive, the regulations concerning prescription will be applied to it. ${ }^{, 21}$

\subsection{The period of prescription, and its modification}

The Proposal does not change the general period of prescription, which lasts 5 years. According to the effective rules:

„Parties shall be entitled to agree on a shorter period of limitation; the agreement shall be valid only in writing. If the period of limitation is shorter than one year, the parties shall be entitled to extend it to a maximum of one year in writing; otherwise, an agreement on the extension of a period of limitation shall be null and void. ",22

${ }^{20}$ The legal determination for prescription isn't homogenous. Period of limitation can also be applied, but we use the term ,prescription”, because the Common Frame of Reference does the same, and in view of its regulation method of prescription - which is in general similar to the Hungarian one - it seems acceptable.

${ }^{21}$ Proposal , Art. 6:21.

${ }^{22}$ The operative Hungarian Civil Code (furthermore: CC) Art. 325, paragraph (2) 
Compared to the effective regulation it is a very significant novelty that parties may deviate from the legal period. At the turn of the 19th and 20th centuries in the civil law literature related to the drafts of Civil code $(1900,1913)$ criticism arose against legal rules excluding or restricting the possibility for extension or curtailing the term of limitation. The binding nature of the term of limitation (or for only in one direction, against its extension) is justified by the legal-political reasons of prescription, which would be harmed either if the parties could prolong the period of limitation without any legal control or if the debtor may waive his objection of prescription in advance. With regard to the fact that parties can reach the same aim with other legal instruments, it is really not necessary to exclude the opportunity of period-changing. However, written form is required for facilitating the burden of proof. At the same time it is to be noticed that the Proposal also forbids the agreement foreclosing the prescription (the objection of prescription) and states that such term shall be deemed null. ${ }^{23}$

\subsection{Legal effects of prescription}

The Proposal does not change the effects of prescription in great extent. "Unless the law prescribes otherwise, a lapsed claim may not be enforced in litigation." It is interesting to notice the change in the text: ,in litigation” instead of ,in court action”. Thus the litigation does not include the proceedings not aiming primarily to assert the right (e.g. probate proceeding) and for the same reason it needs to name the filing of a claim in the course of bankruptcy proceeding beside the judicial enforcement as a condition which interrupts the period of limitation. Contrary to the effective regulation the new provision declares that prescription does not affect the debtor's obligation to fulfil the contract and the performed services cannot be reclaimed on the grounds of prescription. However, we should draw attention to the fact that contrary to the effective law the Proposal ignores the age-long rule according to which the lapse of the claim does not impede the satisfaction from the pledge placed in security thereof. Thus, in lack of particular provision the general rule shall be applied, and pursuant to that all liens shall be terminated upon the expiration of the claim. ${ }^{24}$ According to the commentary for the "new” Civil Code the opportunity of the satisfaction of the timed-barred claim shall be abolished because it harms the legal political purpose of prescription which aims at avoiding the obscure situation of long duration. ${ }^{25}$ Nevertheless, the commentary emphasizes that the period of limitation extinguishes the enforcement in court, while the satisfaction

\footnotetext{
${ }^{23}$ Proposal, Art. 6:22 paragraph (4)

${ }^{24}$ Proposal, Art. 5:140 para. (1)

${ }^{25}$ GÁRDos, Péter (szerk): Handbook for the new Civil Code. Kézikönyv az új Polgári Törvénykönyvhöz. (Complex K., Budapest, 2009.) 469.p.
} 
from pledge is another form of enforcing a claim. The commentary adverts that the lien as a ius in rem cannot be time-barred but in this case the collateral nature being stronger the lien shall also be expired with the lapse of the claim.

The Proposal does not change the provision concerning the prescription of dependent and independent collateral claims. If the principal claim lapses, all of the dependent collateral claims lapse, too. The principal claim shall not be affected when independent collateral claims lapse. ${ }^{26}$

The Proposal declares that the time-barred claims may not be enforced in litigation. But - in contrast to the operative provision - it does not contain the exception as to the time-barred claims must be considered by court in officio in certain cases. From this wording an intention of Legislature can be perceived that the time-barred claims and the extinct right should sharply be distinguished from each other and any legal situation and provision when lapse of claim shall be considered by court is to be cancelled.

It is worth emphasizing that the Proposal in contrast to the new Civil Code edited out the time-barred claim from the list of those claims which cannot be enforced by court action. Thus the Proposal makes a significant distinction between these claims (i.e. moral obligation or naturalis obligatio) and the timebarred claims. Although we can argue that the Proposal partially duplicates the provisions on the claims which may not be enforced by court action, without a good reason, but we can also argue so that a creditor is in a very similar situation arisen either from moral obligation or from lapse, but these legal consequences are based on different legal phenomena. It should be noticed that the moral obligations are placed in the Contract Law (not in the Law of Obligation) in the Proposal after the part relating to invalid and ineffective contracts.

\subsection{The commencement and the suspension of prescription}

The Proposal does not change the provision concerning the commencement of period of prescription. The period commences upon the due date of the claim, it begins to run from the time when the debtor has to affect performance.

The Proposal in a section titled ,,Suspension of period" declares that „If the creditor is unable to enforce a claim for an excusable reason, the period of prescription is suspended. The period of prescription is also suspended as long as the debtor is entitled to refuse performance. ${ }^{27}$

The Proposal does not contain the particular rule whereas ,this provision shall also be applied if the creditor has granted a respite for performance after that period of performance has passed". This change can be explained so that the post-

\footnotetext{
${ }^{26}$ See CC Art. 324. paragraph (2).

${ }^{27}$ Proposal, Art. 6:24. para. (1)
} 
ponement is also meant an excusable reason for the creditor not being able to enforce his claim, therefore the naming of this case is not necessary. Still we can argue that in the judicial practice we can hardly find cases when the petitioner did assign this act as the reason for "suspension" of period. Probably, respite may appear either with written notice for performance of a claim, or with the amendment of a claim by agreement (inclusive of accord), or with the acknowledgment of a debt by the debtor, which facts interrupt the prescription and renew the period, thus, these interrupting events serve more the interests of the creditor.

The Proposal does not enumerate those situations which ,suspend” the period of prescription neither in a taxative (exhaustive) list, nor in any examples contrary to the drafts of Hungarian civil code (in the time of the turn of the 19th and 20th centuries and later). Thus the Proposal is consistent when it does not assign the respite for performance after expiration as suspension event.

Nevertheless, the respite for performance needs further examinations. In case when due to any other excusable reason the creditor is unable to enforce a claim, the claim shall remain enforceable for one year after the cessation of the hindrance or, in respect of a period of limitation of one year or less, for three months, even if the period of limitation has already lapsed or there is less than one year or less than three months, respectively, remaining therein. Thus this rule is relevant only in the case when this excusable hindrance appears close to the end of the period of limitation. In consideration of the respite for performance, if the period of prescription begins to run from this new deadline for performance, the general rule for "suspension" cannot be applied in the case of a 5 year period of limitation. Giving the correct purport of this rule is also problematic. If the period of limitation begins to run from the new deadline for performance, this is the commencement of the period, i.e. the period is simply lengthened, not "suspended" (pursuant to the legal rule for suspension). Considering that the creditor gives the respite for performance after the expiration of the original deadline for performance, there is any excusable hindrance in the beginning of period of prescription, since the rule of suspension can be applied.

The Proposal refines the legal nature of the new period (one year, three months) opened up by the cessation of the hindrance. According to the Proposal this period cannot be suspended, but it can be interrupted applying the provisions on interruption of period of limitation with the difference that the new period of limitation commenced at the time of interruption is one year or three month.

The recent judicial practice does not share this opinion. Pursuant to opinion No 1/2004 (on the interpretation of questions about deficient performance) adopted by Civil Law Chamber of the Supreme Court (Curia) ${ }^{28}$ and to decisions

\footnotetext{
${ }^{28}$ The official name for Supreme Court is Curia from 1st of January 2012.
} 
on individual cases and decisions on principles from the Curia's viewpoint this new period has no prescription characteristics therefore it cannot be interrupted or suspended. In this period the creditor must enforce his claim in court action in this period. We shall pay attention to the fact that this period is not a preclusive term, in this way the court may not take the lapse of the period ex officio into consideration.

In my opinion the text of the Proposal needs to be refined in this respect. On the one hand, regulation should assign that the interruption refers only to the periods which begin to run after the lapsing of the original period of limitation and only the enforcement in litigation could be applied for interrupting the period on the other. Here we must point out the important change - which shall be surveyed below- that the Proposal extinguished the double period (prescription and preclusive term) for enforcing warrant claims flowing from deficient performance, cancelling the preclusive term.

\subsection{The interruption of prescription}

In the Hungarian civil law the interruption of prescription means that events prescribed by law interrupt the period and a new period of prescription begins to run from this event. Under effective law these events are as follows: the written notice for performance of a claim, the acknowledgment of a debt by the debtor, the amendment of a claim by agreement (including the accord), the judicial enforcement of a claim or the filing the claim in bankruptcy process.

The Proposal changes remarkably the list of the events which interrupt the prescription. According to par (1) Art 6:25 the prescription is interrupted by a) the acknowledgment of a debt by the debtor, b) the amendment of a claim by agreement and accord, c) the judicial enforcement of a claim or the filing the claim in bankruptcy process. Thus the written notice for performance is not considered as interrupting event.

Here, the Proposal is based on the early drafts of civil code from the beginning of the 20th century. According to the comment relating to Proposal this event (written notice for performance) conflicts with the legal nature of prescription since it does not aim the enforcing of the claim but drives to the postponement of the period of limitation without reason.

Notwithstanding it is worth holding this legal institution, which has been applied for more than 50 years, considering the following arguments:

1. Since the entry into force of the effective Civil Code this phenomenon has been recognized in the judicial practice and in the economy.

2. The cancellation of this rule strengthened the effect of the interrupting effect of acknowledgment of a debt by the debtor. In this case, the substantiation in litigation aims mainly not the expressive acknowledgment, but ones ex- 
pressed by implied conduct, for example the debtor has received the written notice for performance from the creditor, and he does not deny his debt. Thus the changing of the regulation may result in an "overgrowth" in the field of acknowledgments of a debt.

3. The legal purpose of prescription does not support the cancellation of notice for performance. The governmental justification of the effective Hungarian Civil Code points out that:

,the written notice for performance by creditor as a new periodinterrupting event mightily facilitates the interruption of prescription, but generally the creditor intends to enforce his claim, not to prolong the term of prescription. Anyway, the notice makes it unquestionable that the creditor does not wish to renounce his right. ${ }^{29}$

Thus, we do not need to reject this interrupting event only because it is to be feared that the creditor would abuse this mean and would only aim to extend the period of limitation.

4. The early drafts of the Hungarian Civil Code (e.g. 1900, 1913 and 1928) set the suspending and the interrupting events for the 10,20 and 32 year periods of prescription. In my opinion it is reasonable to keep this interrupting event considering the relatively short (5 year) period of prescription.

The Proposal refines the term of one of the other interrupting events, the enforcing the claim in court. The current term ,judicial enforcement" shall be changed to ,in litigation”, and the filing the claim in bankruptcy process also interrupts the period. The current judicial practice regards the following ways of enforcing a claim in litigation as interrupting event: the filing of an action, the asking for payment order, the interpleader, the filing the claim in bankruptcy process, enforcing a civil law claim in criminal procedure, set-off in the course of court proceedings.

Otherwise the followings cannot be deemed as enforcing a claim in court action: probate proceeding, criminal procedure instituted by private proposal, requesting a preliminary production of evidence but these events may be considered as written notice for performance of a claim. The No 98 / 1973 opinion of the Curia's Civil-Economic Law Chamber - according to which if the party did not accept the call for interpleader, this addressed notice is attributed to written notice for performance a claim - the recent judicial practice does not consider it to be applicable.

It is worth taking into consideration that contrary to the formulation of the operative Civil Code the Proposal lifted the amendment of a claim by agreement beside the acts of enforcement that interrupts the period of the executorial proceedings.

${ }^{29}$ Act No. 4 of year 1959. and the Justification of Hungarian Civil Code [published by Ministry of Justice, KJK, Budapest, 1959.] 248. p. 


\section{Survey of the international law regulations}

In the viewpoint of prescription, it is worth taking into consideration some international uniform law systems. What was chosen are the Draft Common Frame of Reference ${ }^{30}$ (furthermore referred to as DCFR) and the Convention on the Limitation Period in the International Sale of Goods ${ }^{31}$ (furthermore referred to as Limitation Convention). If the DCFR ever gained some mandatory application, its provisions would have to be considered also in the European contractual relationships and these provisions would „overwrite” the Hungarian civil law regulations. To prevent the problems arising from the collision of the national and the European legal regulation, it seems important to consider the provisions of DCFR during the recodification of Hungarian Civil Code. The CISG $^{32}$ Convention adopted by UNCITRAL, to which the Convention on the Limitation Period was added, already has binding force for the cross-border contracts of the Hungarian parties because Hungary is a contracting party to this Convention.

According to all the above mentioned facts, let us overview the familiar and the different provisions of the DCFR and the CISG Limitation Convention along the duration, the commencement, the cessation, the extension, and the renewal of the period.

\subsection{Differences in terminology}

As it is stressed at the very beginning, there is no common terminology for the legal institutions of prescription. On the one hand, the Limitation Convention uses ,period of limitation" for asserting claims, on the other hand the DCFR determines ,period of prescription" for asserting the rights.

\subsection{The duration and the commencement of the period}

The DCFR sets the period in three years while the Limitation Convention in four. Both of these periods are shorter than the Hungarian one. Under the $\mathrm{DCFR}^{33}$ the general period begins to run when the debtor has to affect performance or, in the case of a right to damages, from the time of the act which gives rise to the right. According to the Limitation Convention ,the limitation period

${ }^{30}$ Principles, Definition and Model Rules of European Private Law. Draft Common Frame of Reference (DCFR). Christian von Bar et al. and Hugh Beale et al (ed.) Outline edition, Sellier, Munich 2009. ISBN 978-3-86653-097-3

31 The Convention on the Limitation Period in the International Sale of Goods (hereinafter called as Limitation Convention) was concluded at New York on 14th of June 1974.

${ }^{32}$ United Nations Convention On Contracts For The International Sale Of Goods (1980)

${ }^{33}$ DCFR Art. III.-7:203 para. (1) 
shall commence on the date of which the claim accrues" 34 but it explains further when the claim accrues: in case of breach of contract, when breach occurs, in case of defect or other lack of conformity, the claim accrues on the date which the goods are actually handed over to, or its acceptance is refused by the buyer. The DRAFT and the Limitation Convention are the same in that provisions concerning the period of limitation commences in case of performance by instalment, on the date on which the particular breach occurs, in the case of each separate instalment.

The DCFR allows the parties to modify the period and the requirements for prescription. Thus, they can shorten or lengthen the period between the legal barriers provided the period may not be reduced to less than one or extended to more than 30 years. ${ }^{35}$

The Limitation Convention generally excludes the modification (shortening or lengthening) of the period of limitation but it allows the debtor to lengthen the period at any time during the running of the limitation period. ${ }^{36}$

\subsection{The extension and the cessation of the duration of the period of limitation}

\subsubsection{Suspension in case of ignorance}

It is worth taking into consideration that according to the provision of DCFR, the running of the period is suspended in case of ignorance. ,, The running of the period of prescription is suspended as long as the creditor does not know of, and could not reasonably be expected to know of: (a) the identity of the debtor; or (b) the facts giving rise to the right including, in the case of a right to damages, the type of damage. " ${ }^{37}$ The operative Hungarian regulation and the Limitation Convention do not regulate this case of the suspension in a separate provision. The case of ignorance is taken into account among the cases of the excusable impediments also known as preventing circumstances. The Proposal sets a rule pursuant to which the period is suspended as long as the debtor is able to refuse to perform.

\subsubsection{The judicial proceedings}

The DCFR determines the following cases of the extension: suspension, postponement. The Limitation Convention set events which cause extension. Contrary to the Hungarian operative and new regulations, both model laws set

\footnotetext{
${ }^{34}$ Limitation Convention Art 9. para 1.

${ }^{35}$ See DCFR Art. III. -7:601.

${ }^{36}$ Limitation Convention Art. 22.

${ }^{37}$ DCFR Art. III.-7:301.
} 
the events in which case the period can be extended. At first sight we can perceive not only the differences in wording between DCFR, Limitation Convention and the Hungarian rules, but that DCFR regards the judicial proceedings as events affecting the running of the period of limitation in a different way from the Hungarian Civil Code. According to the DCFR the legal act as initializing the proceedings aiming to assert the claims merely suspends the passing of the period, and the further running of the period depends on the "success" of the judicial proceedings. If the proceedings end with a decision which has the effect of res judicata, the suspension ceases. ${ }^{38}$ Contrary to this rule, the Limitation Convention regards the judicial proceedings as an event which ceases the limitation period. ,"The limitation period shall cease to run when the creditor performs any act which, under the law of the court where the proceedings are instituted, is recognized as commencing judicial proceedings against the debtor or as asserting his claim in such proceedings already instituted against the debtor, for the purpose of obtaining satisfaction or recognition of his claim. "39

According to the DCFR the suspension of prescription does occur in the case when the judicial proceedings are started and it lasts until a decision which has the effect of res judicata. If the court cannot deliver a decision on the merits of the case and if that the period has less than six month to run, the period of prescription does not expire before six months have passed after the time when the proceedings ended.

It is worth taking into consideration here that DCFR does not express the consequences in the case if the original period of limitation has already expired before the judicial proceedings ended. Whether the limitation period can be suspended if the impediment event becomes extinct after the expiration of the original limitation period is a question to be answered by the judicial practice if the DCFR shall ever become applicable.

According to the Limitation Convention if the judicial proceedings ended without decision on the merits, ,it shall be deemed to have continued to run" (it did not cease $)^{40}$. Thus, there is a case when the suspension came from the situation of cessation: ,If, at the time such legal proceedings ended, the limitation period has expired or has less than one year to run, the creditor shall be enti-

${ }^{38}$ DCFR, Art. III.-302. [Suspension in case of judicial and other proceedings] (1) The running of the period of prescription is suspended from the time when judicial proceedings to assert the right are begun" (2) Suspension lasts until a decision has been made which has the effect of res judicata, or until the case has been otherwise disposed of. Where the proceedings end within the last six month of the prescription period without a decision on the merits, the period of prescription does not expire before six month have passed after the time when the proceedings ended.,

${ }^{39}$ Limitation Convention Art. 13.

${ }^{40}$ Limitation Convention Art. 17. par. 1. 
tled to a period of one year from the date on which the legal proceedings ended."

Comparing to the Hungarian regulation, the operative and the new provisions of Hungarian Civil Code regard the commencement of the judicial proceedings as an event which interrupts, i.e. ceases the period of limitation. A new period of limitation begins to run also in the case if the proceedings ended without decision binding on the merits. However, the new period shall begin to run only if a decision is delivered and has the effect of res judicata.

\subsubsection{Impediment beyond the creditor's control and other circumstances}

The Limitation Convention declares other case of the extension. „Where, as a result of a circumstance which is beyond the control of the creditor and which he could neither avoid nor overcome, the creditor has been prevented from causing the limitation period to cease to run, the limitation period shall be extended so as not to expire before the expiration of one year from the date on which the relevant circumstance ceased to exist." 41 In this provision it is worth examining whether the limitation period can be extended due to the relevant circumstance if the circumstance ceases to exist on the date when the period of limitation has already expired.

„When a circumstance as defined in Art. 21 occurs, the period keeps on running. However, it does not expire at the time at which it would normally expire, unless that time is more than one year after the relevant circumstance ceased to exist. The end of that year marks the earliest possible end of the period." 42 "Thus if, at the time the preventing circumstance ceased to exist, the limitation period had expired or had less than one year to run, the creditor is given one year from the date on which the preventing circumstance ceased to exist." 43 The Limitation Convention does not explain which circumstances cause the period to extend, but according to the Commentary ${ }^{44}$ these are the following: a state of war or the interruption of communications; the death or incapacity of the debtor where an administrator of the debtor's assets has not yet been appointed; the debtor's misstatement or concealment of his identity or

${ }^{41}$ Limitation Convention Art 21.

42 see: Hans SMIT: The Convention on the Limitation Period in the International Sale of Goods: UNCITRAL's First Born. http://www.cisg.law.pace.edu/cisg/biblio/smit.html\#ix downloaded: 11th of June 2012.

${ }^{43}$ see: I. Commentary on the Convention on the Limitation Period in the International Sale Of Goods, done At New York, 14 June 1974. by Professor Kazuaki SonO in Japanese. 2012 .

http://www.cisg.law.pace.edu/cisg/biblio/sono1.html\#art21 downloaded: 11th of June

${ }^{44}$ I. Commentary by Professor Kazuaki SoNO op. cit. 
address which prevents the creditor from instituting legal proceedings; fraudulent concealment by the debtor of defects in the goods.

Due to these circumstances, the DCFR determines a case for suspension of the period of prescription and a lot of cases for postponement of expiry. „The running of the period of prescription is suspended as long as the creditor is prevented from pursuing proceedings to assert the right by an impediment which is beyond the creditor's control and which the creditor could not reasonably have been expected to avoid or overcome." This rule is only relevant if the impediment occurs or subsists within the last six month of the period. But these circumstances do not automatically suspend the period, only in the case if, due to these impediments, it is unreasonable to expect to the creditor to take proceedings to assert the right. This suspension last six months after the impediment ceases to exist.

The DCFR, contrary to the Limitation Convention, does name other circumstances in particular headings for postponement: Postponement of expiry in case of negotiations ${ }^{45}$, Postponement of expiry in case of incapacity ${ }^{46}$, Postponement of expiry: deceased's estate ${ }^{47}$. In these cases the period of prescription does not expire before one year has passed after these circumstances come to an end.

\subsection{The renewal of the period}

The DCFR use the term ,renewal” instead of the terminology of Limitation Convention (cessation of the period), but both apply similar rules for the interrupting events. It must be noticed that both make no mention about the written notice for performance as interrupting event. The Limitation Convention, however, sets that ,Where the creditor performs, in the State in which the debtor has his place of business and before the expiration of the limitation period, any act, [...], which under the law of that State has the effect of recommencing a limitation period, a new limitation period of four years shall commence on the date prescribed by that law. "48 Thus, pursuant to this provision, the provision of the Hungarian Civil Code is applicable, and the written notice for performance interrupts the period, too.

The DCFR and the Limitation Convention regulate the acknowledgement of debtor as an event which interrupts the running the period and renews it. Pursuant the Limitation Convention: ,Where the debtor, before the expiration of the limitation period, acknowledges in writing his obligation to the creditor,

\footnotetext{
${ }^{45}$ DCFR Art. III.-7:304.

${ }^{46}$ DCFR Art. III.-7:305.

${ }^{47}$ DCFR Art. III.-7:306.

${ }^{48}$ Limitation Convention Art. 19.
} 
a new limitation period of four years shall commence to run from the date of such acknowledgement." "49 According to the DCFR: "If the debtor acknowledges the right, vis-à-vis the creditor, by part payment, payment of interest, giving of security, or in any other manner, a new period of prescription begins to run. " $"$ But the Limitation Convention also adds other acts by the debtor which are deemed as acknowledgement: payment of interest or partial performance of an obligation by the debtor.

Taking into consideration the similar manner of the regulation, it is presumed that these acts shall be incorporated to the new Hungarian Civil Code, too.

\subsection{General limit of the limitation period}

Contrary to the Hungarian Civil Code, the DCFR and the Limitation Conventions set a period of maximum length for the prescription. This general limit is 10 years pursuant to the Limitation Convention and to DCFR as well. DCFR sets an exception to the rights to damages for personal injuries which means 32 years for prescription.

If the Legislature of the new Hungarian Civil Code would not cease the written notice for performance as an interrupting event, it should be worth deliberating to enter a general time limit for prescription. In the case of the time limits for enforcement of claims arising from deficient performance the preclusive period shall be retained by all means.

\subsection{Consequences of the expiry of the limitation period}

Corresponding to the Hungarian regulation, pursuant to the Limitation Convention the condition for the consequences is the objection of the debtor. „Expiration of the limitation period shall be taken into consideration in any legal proceedings only if invoked by a party to such proceedings. ${ }^{, 51}$ The DCFR does not set this rule, it simply says: „After expiry of the period of prescription the debtor is entitled to refuse performance. ",52

Both systems of regulation set the rule according to which ,, Whatever has been paid or transferred by the debtor in performance of the obligation may not be reclaimed merely because the period of prescription has expired."53 This reclaim cannot be asserted in the case if the debtor did not even know that the period has expired when he performed his obligation.

\footnotetext{
${ }^{49}$ Limitation Convention Art. 20.

${ }^{50}$ DCFR Art. III.-7:401.

${ }^{51}$ Limitation Convention Art 24.

${ }^{52}$ DCFR Art. III.-7:501.

${ }^{53}$ DCFR Art. III.-7:501. para. 2.
} 
Both ,model" laws accept the rule of the set-off of the expired claim, but put up different condition for that. ,A right in relation to which the period of prescription has expired may nonetheless be set off, unless the debtor has invoked prescription previously or does so within two months of notification of set-off." "N4 "Notwithstanding the expiration of the limitation period one party may rely on his claim as a defence or for the purpose of set-off against a claim asserted by the other party, provided that in the latter case this may only be done: (a) if both claims relate to the same contract or to several contracts concluded in the course of the same transaction; or (b) if the claims could have been set-off at any time before the expiration of the limitation period." 55

The Limitation Convention does not touch upon the prescription of all the other rights of an ancillary nature, but on the obligation to pay interest either the Limitation Convention or the DCFR declares that the expiration of the limitation period with respect to a principal debt shall have the same effect with respect to an obligation to pay interest on the debt, i.e. its period of limitation expires not later than the period for the principal right.

The Limitation Convention excludes liens, mortgages and other security interests in property from its scope, so it does not determine the legal effect of the prescription of the principal right upon the ancillary rights, such as lien (pledge). The DCFR, however, sets rules for the proprietary security in movable assets, and determines the legal effect of prescription upon the pledge. ,A security right can be enforced even if the secured right is prescribed and up to two years after the debtor of the secured right has invoked this prescription as against its creditor. ",56

\section{Conclusions}

The new Proposal of the Hungarian Civil Code brings significant amendments in the field of the prescription. A survey of the new provisions, the achievements of the judicial practice and certain model laws on prescription demonstrates that there are still questions which need to be answered before the new Civil Code of Hungary comes into force. The distinction between limitation period and preclusive period is particularly important and it must be cleared even before the judicial practice has formed a standpoint on this subject matter.

\footnotetext{
${ }^{54}$ DCFR Art. III.-7:503.

${ }^{55}$ Limitation Convention Art 25.

${ }^{56}$ DCFR Art IX.-6:103.
} 
Река Пусииахељи, асисиений

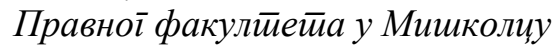

\section{Рокови за остварење потраживања и вршење права: преклузивни рокови и рокови застарелости према Предлогу новог грађанског законика Мађарске}

\section{Сажейик}

Влада Републике Мађарске је 11. јула 2012. године Народној скупштини упутила Предлог новог грађанског законика. У њему се предлажу нова правила о роковима застарелости и преклузивним роковима, с циљем да се позитивно правна регулатива усклади са постојећом судском праксом, међународним изворима права и традицијом мађарског приватног права. Аутор у овом раду анализира поједина нова нормативна решења Предлога која се тичу застарелости и преклузије, с посебним освртом на питање њихове међусобне усклађености. Аутор компаративним методом разматра и сходне одредбе Нацрта заједничких оквирних правила (Draft Common Frame of Reference) и Конвенције о застарелости потраживања у области међународне купопродаје робе, усвојене 1974. године у Њујорку.

Кључне речи: застарелост, рок застарелости, преклузивни рок 